\title{
INVESTMENT TREATY ARBITRATION POST-ABACLAT: TOWARDS A TAXONOMY OF 'MASS' CLAIMS
}

\author{
Manish Aggarwal \\ Simon Maynard ${ }^{\dagger}$
}

\begin{abstract}
This article examines the jurisdictional awards in two pending ICSID cases against Argentina-Abaclat and Ambiente - that allowed a multitude of Italian bondholders affected by Argentina's sovereign debt default to collectively use the investment treaty arbitration process, without requiring any additional or specific consent from the state.

Such collective proceedings raise complex issues in relation to the state consentcentric paradigm of international investment law. The article considers the following distinct, but nevertheless interrelated, matters arising from the Abaclat and Ambiente awards, in an attempt to identify a taxonomy of collective or multi-party claims in international investment law: (i) characterisation of the nature of the proceedings; (ii) whether a host state's general consent to arbitration can be taken to include consent to being sued by multiple investors in one and the same arbitral proceeding; (iii) interpretation of the silence regarding the issue of collective proceedings in the current legal framework under the ICSID Convention; and (iv) whether collective proceedings require a certain link or relationship between the co-claimants, their respective investments and/or claims.
\end{abstract}

\section{Keywords}

Investment arbitration, mass claims

\section{Introduction}

Its critics notwithstanding, investment treaty arbitration provides investors with a unique mechanism for seeking redress for states' internationally wrongful acts. ${ }^{1}$

\footnotetext{
Associate, Three Crowns, London.

† Associate, Allen \& Overy, London. The views expressed in this article are those of the authors and do not necessarily reflect the views of Three Crowns, Allen \& Overy, or their respective clients.

1 For a detailed account of the historical origins of international investment law, see A Newcombe \& L Paradell, Law and Practice of Investment Treaties: Standards of Treatment (2009) ch 1.
}

Copyright $\odot$ the Author(s).

This work is licensed under a Creative Commons Attribution-NonCommercial-NoDerivs 3.0 License. 
Since the 'baby boom' of investor-state dispute settlement (ISDS), ${ }^{2}$ foreign investors in a variety of economic sectors have been able to access an international arbitral regime-pursuant to various international investment agreements (IIAs)-beyond the domestic legal framework of the host state.

The system of investment treaty arbitration thus represents a far reaching consent-based mechanism for access to the protection of international law. Indeed, a number of commentators have characterised the international investment regime as a type of 'global administrative law' ${ }^{3}$ or 'global governance' regime, ${ }^{4}$ which is concerned with the exercise of public authority by bodies outside the State, and by States in ways that reach beyond the State and its law'.

Although much has been written recently of a backlash against ISDS, ${ }^{6}$ the system continues to expand. A recent UNCTAD study indicates that, in 2013, investors initiated 57 new ISDS cases pursuant to various IIAs. ${ }^{7}$ In fact, the total number of known treaty-based cases had reached 568 by the end of 2013. ${ }^{8}$ Not only does the number of ISDS claims continue to increase under existing IIAs year on year, but new international treaties with ISDS provisions are also being concluded. At the time of writing of this article, negotiations are well underway on the Transatlantic Trade and Investment Partnership, the Trans-Pacific Partnership and various other free trade agreements, many of which might include ISDS provisions.

This article addresses some recent developments that have potentially extended the reach of treaty arbitration, possibly making it available to new investors and in new scenarios. In particular, it examines the jurisdictional awards in two recent cases under the Convention on the Settlement of Investment Disputes between States and Nationals of other States (ICSID Convention) ${ }^{9}$ against

2 See S Alexandrov, "The "Baby Boom” of Treaty-Based Arbitrations and the Jurisdiction of ICSID Tribunals' (2005) 6 JWIT 387.

3 G Van Harten \& M Loughlin, 'Investment Treaty Arbitration as a Species of Global Administrative Law' (2006) 17 EJIL 121.

${ }^{4}$ B Kingsbury \& S W Schill, 'Investor-State Arbitration as Governance: Fair and Equitable Treatment, Proportionality and the Emerging Global Administrative Law', in A Jan van den Berg (ed), 50 Years of the New York Convention: ICCA International Arbitration Conference (2009) 5, 5.

5 Ibid, 10 .

${ }^{6}$ See e.g. M Waibel, A Kaushal, H-W Chung \& C Balchin (eds), The Backlash against Investment Arbitration (2010).

7 UNCTAD Issues Note, Recent Developments in Investor-State Dispute Settlement, UN Doc UNCTAD/WEB/DIAE/PCB/2014/3 (7 April 2014) 2.

${ }^{8}$ Ibid, 7.

9 Convention on the Settlement of Investment Disputes Between States and Nationals of Other States, 18 March 1965, 575 UNTS 159. 
Argentina-Abaclat ${ }^{10}$ and Ambiente ${ }^{11}$-that allowed a multitude of Italian bondholders affected by Argentina's sovereign debt default to collectively use the investment treaty arbitration process, without requiring any additional or specific consent from Argentina.

Such collective proceedings raise complex issues in relation to the state consent-centric paradigm of international investment law. This article does not purport to be a comprehensive examination of all the relevant issues. Instead, it is confined to an examination of the following distinct, but nevertheless interrelated, matters arising from the Abaclat and Ambiente awards, in an attempt to identify a taxonomy of collective or multi-party claims/proceedings in international investment law: (i) characterisation of the nature of the proceedings; (ii) whether a host State's general consent to arbitration can be taken to include consent to being sued by multiple investors in one and the same arbitral proceeding; (iii) interpretation of the silence regarding the issue of collective proceedings in the current legal framework under the ICSID Convention; and (iv) whether collective proceedings require a certain link or relationship between the co-claimants, their respective investments and/or claims.

In particular, this article does not deal with the issue of collective or class proceeding in the context of contract-based commercial arbitrations, which may be subject to different interpretative techniques. A comparative analysis of the national law jurisprudence relating to mass or collective arbitrations is also beyond the scope of this article. Finally, the authors do not express any views on broader questions relating to the propriety of mass or collective claims in international investment arbitration, or the appropriateness of treaty arbitration in the context of sovereign debt restructuring.

\footnotetext{
${ }^{10}$ Abaclat and others $v$ Argentine Republic, ICSID Case No ARB/07/5 (Decision on Jurisdiction and Admissibility, 4 August 2011); Abaclat v Argentine Republic (Decision on Jurisdiction and Admissibility, Dissenting Opinion, Georges Abi-Saab, 28 October 2011).

${ }^{11}$ Ambiente Ufficio SPA and others v Argentine Republic, ICSID Case No ARB/08/9 (Decision on Jurisdiction and Admissibility, 8 February 2013); Ambiente v Argentine Republic (Decision on Jurisdiction and Admissibility, Dissenting Opinion, Santiago Torres Bernardez, 2 May 2013).
} 


\section{Abaclat and Ambiente: Extending the reach of treaty arbitration?}

\subsection{Factual background}

The Abaclat and Ambiente cases arose out of the same factual background when, as part of its efforts to restructure its sovereign debt following its 2001 financial crisis, Argentina offered to exchange existing Argentine debt instruments (including bonds) for new debt instruments valued at around 35\% of the value of the original debt instruments. ${ }^{12}$ The claimants in Abaclat and Ambiente cases are Italian bondholders who refused to accept this offer.

Both claims were commenced under the ICSID Convention pursuant to the ISDS provisions in the Agreement between the Argentine Republic and the Republic of Italy on the Promotion and Protection of Investments, signed on 22 May 1990 (Argentina-Italy BIT). The Abaclat claimants were represented in the proceedings by Task Force Argentina (TFA), an association of eight major Italian banks established in 2002, while the Ambiente claimants were also represented by a third-party, the North Atlantic Société d'Administration (NASAM). ${ }^{13}$

On 4 August 2011 and 8 February 2013, respectively, the ICSID Tribunals in Abaclat $^{14}$ and Ambiente ${ }^{15}$ issued majority decisions on jurisdiction and admissibility, accepting to hear claims by about 60,000 (Abaclat) and 90 (Ambiente) Italian bondholders. ${ }^{16}$ These majority decisions were followed by strong dissenting opinions. ${ }^{17}$

\footnotetext{
$\overline{12}$ A third case arising out of Argentina's 2001 sovereign bond default, Giovanni Alemanni and others $v$ Argentine Republic, ICSID Case No ARB/07/8, has yet to reach a decision on issues of jurisdiction and admissibility.

${ }^{13}$ Ambiente v Argentine Republic (Decision on Jurisdiction and Admissibility, 8 February 2013) paras 273-78.

${ }^{14}$ Abaclat v Argentine Republic (Decision on Jurisdiction and Admissibility, 4 August 2011).

${ }^{15}$ Ambiente v Argentine Republic (Decision on Jurisdiction and Admissibility, 8 February 2013).

${ }^{16}$ Following Argentina's second exchange offer in 2010, the number of claimants pursuing the Abaclat arbitration decreased from 180,000 to approximately 60,000, and the number pursuing the Ambiente arbitration from 119 to 90.

${ }^{17}$ Abaclat $v$ Argentine Republic (Decision on Jurisdiction and Admissibility, Dissenting Opinion, Georges Abi-Saab, 28 October 2011); Ambiente v Argentine Republic (Decision on Jurisdiction and Admissibility, Dissenting Opinion, Santiago Torres Bernardez, 2 May 2013).
} 


\subsection{Characterisation of the proceedings}

Before delving into the jurisdictional and admissibility objections made by Argentina, the tribunals in both Abaclat and Ambiente first sought to characterise the precise nature of the collective actions before them.

\subsubsection{Abaclat}

The manner in which the majority in Abaclat characterised the arbitration proceedings was a key plank of its reasoning in respect of jurisdiction and admissibility. It began by noting that there was no 'uniform terminology concerning the various kinds of proceedings involving a high number of parties.' ${ }^{18}$ It was, therefore, only for the 'sake of simplicity and clarity' that the majority described the claim as 'mass proceedings', where that term was to be understood as 'referring simply to the high number of claimants appearing together as one mass' and not as any 'prejudgment of the procedural classification' of the arbitration. ${ }^{19}$

The majority then proceeded to classify mass claims into two main categories of 'collective proceedings', namely:

- Representative proceedings: Where high number of claims arise as one single action; for instance, an action brought by a representative in the name of a class composed of an indeterminate number of unidentified claimants. The most well-known example is that of class actions in the US.

- Aggregate proceedings: Where claims are aggregated judicially and managed together. The majority gave the example of the English Group Litigation Order, whereby the court requires a large number of claims arising out of the same fact pattern to be tried before a single judge in the interests of procedural efficiency. ${ }^{20}$

In the majority's view, the proceedings did not fall squarely within either category. It noted that the proceedings appeared to be aggregate proceedings in which each individual claimant was aware of and consented to the ICSID arbitration. As such, given that the number and identity of claimants was

\footnotetext{
${ }_{18}$ Abaclat v Argentine Republic (Decision on Jurisdiction and Admissibility, 4 August 2011) para 480.

19 Ibid.

${ }^{20}$ Ibid, para 483.
} 
established, the proceedings could not be compared to a US class-action. ${ }^{21}$ However, the majority also found that some of the features of the proceedings' conduct resembled a representative action. Although each claimant made an 'individual and conscious choice' to participate in the arbitration, thereafter that participation was passive because a third-party (TFA) represented its interests and made decisions on its behalf in relation to the conduct of the proceedings. Further, because of the number of claimants, that representative could not consider the individual interests of particular claimants but rather was limited to the defence of interests common to the entire group. ${ }^{22}$

Ultimately, the majority concluded that the proceedings were a 'hybrid kind of collective proceedings', which started as 'aggregate proceedings' but then continued with 'features similar to representative proceedings. ${ }^{23}$

The majority's characterisation attracted scathing criticism in Arbitrator AbiSaab's dissenting opinion, who colourfully described the 'hybrid' as a 'brain-child of the majority award's legal imagination ${ }^{24}$ and 'legal genetic engineering' which risked 'producing a monster. ${ }^{25}$ In his view, the various claims continued to retain their 'individualized' character even after aggregation, and were thus not capable of being treated judicially as one claim. ${ }^{26}$

\subsubsection{Ambiente}

The Ambiente majority noted that, insofar as the terms 'collective action' or 'aggregate proceedings' were not technical terms with a fixed meaning (at least within the framework of the ICSID Convention), it had no principled objections against using these terms. ${ }^{27}$

However, the majority expressly rejected any characterisation of the dispute as a 'class' action. ${ }^{28}$ It considered that, despite the existence of a joint representative (NASAM) for all the claimants, the proceedings did not incorporate any aspects of a representative proceeding, given that the claimants were clearly

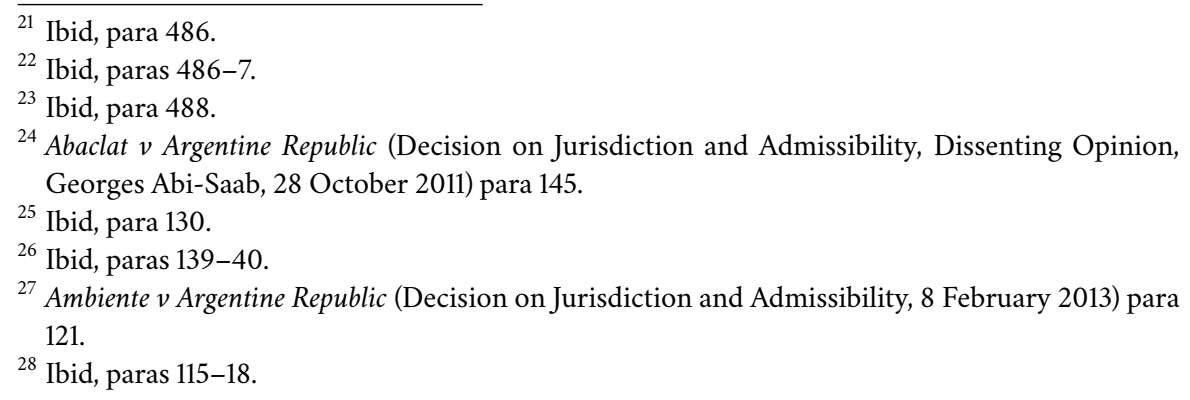


identified individuals acting in their own names and that the Tribunal's findings would only be binding upon the claimants and not on any third-party, including NASAM.

The majority also departed from the 'mass' claim characterisation adopted in Abaclat. ${ }^{29}$ It noted that the term 'mass' was not a technical term, and noted that it could not be precisely defined when a multitude of claimants turns into a 'mass' of claimants. ${ }^{30}$ In particular, the majority was influenced by the difference in magnitude of the disputes in Abaclat and Ambiente. It made pains to stress that, insofar as the terms 'mass' claim or proceeding might imply that the 'sheer number of claimants in itself calls for modifications or adaptations of the procedural arrangements to guarantee the manageability or fairness of the case', it saw no such implications arising from the number of claimants in the Ambiente proceedings. ${ }^{31}$ To avoid any confusion, it preferred to characterise the Ambiente proceedings as a 'multi-party' action. ${ }^{32}$

For the purpose of this article, and without using these terms in any technical sense or drawing any conclusion as to the appropriateness or relevance of such labels, we will use the broad expression 'collective proceedings' to refer to such large-scale arbitrations, which may, depending upon context, refer both to 'mass' (as in Abaclat) and to 'multi-party' (as in Ambiente) claims or proceedings.

\subsection{Host state's consent to collective proceedings}

In relation to the matter of collective proceedings, both the Abaclat and Ambiente tribunals had to consider objections to jurisdiction based on the respondent state's consent to ICSID arbitration. In particular, the tribunals examined the question whether, in the absence of any explicit reference to collective proceedings, Argentina's general consent to ICSID arbitration under the Argentina-Italy BIT was sufficient to encompass consent to claims by multiple claimants being brought against it in one single arbitration proceeding. ${ }^{33}$

${ }^{29}$ Ibid, paras 119-22.

${ }^{30}$ Ibid, para 119.

31 Ibid, para 120.

32 Ibid, para 122.

${ }^{33}$ Abaclat $v$ Argentine Republic (Decision on Jurisdiction and Admissibility, 4 August 2011) para 489 ('The only remaining question is whether a specific consent regarding the specific conditions in which the present arbitration would be conducted is required, i.e., regarding the form of collective proceedings'); Ambiente $v$ Argentine Republic (Decision on Jurisdiction and Admissibility, 8 February 2013) para 145, noting that the pertinent question was 'whether, within the framework of the ICSID Convention, the original submission of multi-party claims requires a specific or 


\subsubsection{Majority view}

The majority in Abaclat answered this question in the affirmative on the basis that:

Assuming that the Tribunal has jurisdiction over the claims of several individual Claimants, it is difficult to conceive why and how the Tribunal could lose such jurisdiction where the number of Claimants outgrows a certain threshold. First of all, what is the relevant threshold? And second, can the Tribunal really 'lose' a jurisdiction it has when looking at Claimants individually ? ${ }^{34}$

The majority in Ambiente endorsed this approach. It also undertook a textual examination of the ICSID Convention ${ }^{35}$ and the Argentina-Italy BIT, ${ }^{36}$ as well as an analysis of the travaux preparatoires of the ICSID Convention, ${ }^{37}$ commentaries $^{38}$ and past multi-party ICSID arbitrations, ${ }^{39}$ before concluding that 'the ICSID Convention, the Argentina-Italy BIT and other applicable rules in the present dispute are not opposed to a plurality of claimants jointly submitting a claim to the Centre. ${ }^{40}$ The majority also emphasised that it was unnecessary to require a specific or additional consent on the part of Argentina beyond the prerequisite of written consent under Article 25(1) of the ICSID Convention, because the dispute did not constitute a consolidated or joined proceeding ${ }^{41}$ and because no other investment dispute that was initially filed as a multi-party

additional act of consent on the part of the Respondent beyond the general consent requirement pursuant to Art 25(1) of the Convention'.

${ }^{34}$ Abaclat $v$ Argentine Republic (Decision on Jurisdiction and Admissibility, 4 August 2011) para 490.

${ }^{35}$ Ambiente $v$ Argentine Republic (Decision on Jurisdiction and Admissibility, 8 February 2013) para 130: 'While it is true that the provision [Article 25 ICSID Convention] speaks of national of [a] Contracting State in the singular, nothing would force the Tribunal to conclude that this wording could not also encompass a plurality of individuals'.

${ }^{36}$ Ibid, para 131.

${ }^{37}$ Ibid, para 132.

38 Ibid, paras 142-3.

${ }^{39}$ Ibid, paras $135-1$.

${ }^{40}$ Ibid, para 146.

${ }^{41}$ Ibid, paras 123-5, citing G Kaufmann-Kohler et al, 'Consolidation of Proceedings in Investment Arbitration: How Can Multiple Proceedings Arising from the Same or Related Situations be Handled Efficiently? - Final Report on the Geneva Colloquium held on 22 April 2006' (2006) 21 ICSID Rev-FILJ 59, and distinguishing between a multi-party proceeding where plurality of investors together commence one single arbitration against the host State, and 'consolidation' in its traditional sense which covers joinder of two or more separate proceedings that already are pending before different courts or arbitral tribunals (which the Majority admitted required a specific consent of the parties). For a recent instance of consolidation with parties' consent see 
proceeding required separate consent to establish the propriety of multi-party proceedings. ${ }^{42}$

In addition, both the Abaclat and Ambiente Majority considered that, insofar as sovereign bonds qualified as investments under the relevant BIT providing for ICSID arbitration, it was in their nature (because they are held by a large number of investors) to lead to collective proceedings and, hence, any consent to ICSID arbitration in such BITs should be treated as encompassing the form of arbitration (including collective proceedings) necessary to provide effective protection to such investments. ${ }^{43}$

\subsubsection{Dissenting view}

The majority in Abaclat had reasoned that the 'mass' aspect of the proceedings was a question of admissibility, which pertained to the 'modalities and implementation of the ICSID proceedings' and not to the issue as to whether the respondent state had consented to ICSID arbitration. ${ }^{44}$ In contrast, in Arbitrator Abi-Saab's dissenting view in Abaclat, Argentina's objection went to the scope of its consent to arbitrate. Drawing on the recent US Supreme Court decisions on class arbitrations in Stolt-Nielsen SA v AnimalFeeds Int'l Corp ${ }^{45}$ and AT\&T Mobility LLC v Concepcion, ${ }^{46}$ he found that there was a fundamental difference between regular bilateral arbitration and mass proceedings that 'changes the nature of arbitration, ${ }^{47}$ and concluded that:

[...] in conformity with what is followed both on the national law level, including in international commercial arbitration, and on the international law level, which is the applicable law in the present

Churchill Mining Plc v Republic Indonesia and Planet Mining Pty Ltd v Republic of Indonesia, ICSID Case Nos ARB/12/14 \& ARB/12/40 (Procedural Order No 4, 1 March 2013).

${ }^{42}$ Ambiente $v$ Argentine Republic (Decision on Jurisdiction and Admissibility, 8 February 2013) para 141: '[I]t is evident that multi-party arbitration is a generally accepted practice in ICSID arbitration, and in the arbitral practice beyond that, and that the institution of multi-party proceedings therefore does not require any consent on the part of the respondent Government beyond the general requirements of consent to arbitration'.

${ }^{43}$ Ibid, para 144; Abaclat v Argentine Republic (Decision on Jurisdiction and Admissibility, 4 August 2011) para 518.

${ }^{44}$ Ibid, paras 491-2.

${ }^{45} 130$ S Ct 1758 (2010).

${ }^{46} 131 \mathrm{~S}$ Ct 1740 (2011).

${ }^{47}$ Abaclat $v$ Argentine Republic (Decision on Jurisdiction and Admissibility, Dissenting Opinion, Georges Abi-Saab, 28 October 2011) paras 146-53. 
case, a mere acceptance to arbitrate does not cover collective mass claims actions (regardless of the denomination) and that a special or secondary consent is needed for such collective actions. ${ }^{48}$

In his dissenting opinion in Ambiente, Arbitrator Santiago Torres Bernárdez observed that 'representative' mass proceedings fell outside the framework of the ICSID system in light of the silence of the ICSID basic texts, which could not be remedied even by the consent of a given respondent state. ${ }^{49}$ However, in the case of an 'aggregate proceeding' (namely, a proceeding allowing due process examination of each individual claim forming part of the multi-party action), the silence in the ICSID texts and in the relevant BIT regarding the admissibility of collective forms of action was capable of being 'remedied by an ad hoc additional manifestation of consent to the "multi-party proceeding" concerned on the part of the respondent. ${ }^{50}$ However, he found that, in the Ambiente case, the silence had not been remedied by an additional consent of Argentina as the respondent State, either in its offer to arbitrate contained in the Argentina-Italy BIT or in any ad hoc manner. ${ }^{51}$

Both dissenting opinions also concluded that, in ICSID practice, cases of multi-party arbitration had either proceeded with the 'clear agreement' of the parties or without objection from the respondent state (which amounted to implied consent), and hence, 'the rule of "secondary consent" was consistently upheld in multi-party arbitration. ${ }^{52}$

\subsubsection{Analysis}

The Majority view in Abaclat and Ambiente in relation to the question of the host State's consent to collective procedures has been criticised by some commentators. ${ }^{53}$ For instance, one commentator has noted:

\footnotetext{
${ }^{48}$ Ibid, para 190.

${ }^{49}$ Ambiente v Argentine Republic (Decision on Jurisdiction and Admissibility, Dissenting Opinion, Santiago Torres Bernardez, 2 May 2013) paras 99, 104.

${ }^{50}$ Ibid, para 100.

51 Ibid, para 101.

${ }^{52}$ Abaclat $v$ Argentine Republic (Decision on Jurisdiction and Admissibility, Dissenting Opinion, Georges Abi-Saab, 28 October 2011) para 175; Ambiente v Argentine Republic (Decision on Jurisdiction and Admissibility, Dissenting Opinion, Santiago Torres Bernardez, 2 May 2013) para 105.

53 See e.g. D Leavitt, 'Disputing The Dispute: Amending International Arbitral Tribunal Rules To Require Secondary Consent For Class Arbitration' (2013) 4 Creighton ICLJ 15, noting that Abaclat assumption, which assumes 'consent' to individual arbitration simultaneously constitutes class
} 
The majority approach [in Abaclat] to the issue of consent overlooks two fundamental aspects of international law. First, consent to arbitrate does not of itself mean consent to consolidation or consent to be sued by multiple parties in a single arbitration. Consent (particularly consent to consolidation), therefore, should be a matter of jurisdiction alone, not a matter of both admissibility and jurisdiction. Second, [...] by refusing to enquire as to whether Argentina had actually consented to mass proceedings (and considering instead whether such claims were simply permissible), the majority's approach ignores the object and purpose of the BIT/ICSID Convention. $^{54}$

However, other commentators have endorsed the majority's approach by reference to the fundamental differences between commercial and investment treaty arbitration. According to this school of thought, consent in commercial arbitration arises from a direct contractual agreement between specific and identifiable parties and, absent evidence of a prior meeting of the minds between the parties for purposes of formation of the agreement to arbitrate, there is no consent and thus no jurisdiction. Conversely, the nature of consent in investment treaty arbitration is entirely different. An investment treaty is not a contractual relationship between the state and certain specific individual investors identified in the treaty itself. On the other hand, great majority of investment treaties contain a host state's consent to arbitrate (in the form of a unilateral, standing offer) that is capable of acceptance by any investor meeting the conditions specified in the treaty. Where more than one investor accepts the state's unilateral offer to arbitrate, investment treaties do not contain any provision stating that the offer is invalidated or made subject to a further jurisdictional hurdle. The host state's offer to arbitrate is thus 'inherently' directed to a multitude of potential qualifying investors (i.e., all investors with protected investments) and it is, therefore, 'inherent' in this consent mechanism that the state parties can be confronted with multiple claimants for disputes arising out of the same factual situation. $^{55}$

arbitration, is flawed.

${ }^{54}$ M Weiniger \& M McClure, 'Looking to the Future: Three "Hot Topics" for Investment Treaty Arbitration in the Next Ten Years' (2013) 10(4) TDM 1, 4.

${ }^{55}$ For a succinct summary of this line of argument, see A Newcombe, 'Mass claims and the distinction between jurisdiction and admissibility (Part II)' (Kluwer Arbitration Blog, 16 December 2011) <http://kluwerarbitrationblog.com/blog/2011/12/16/mass-claims-and-the- 
In addition, the majority view has been supported by some commentators by emphasising the 'temporal asymmetry' in terms of the timing of expression of consent to investment arbitration by each of the investor and the host state: the host state generally gives its consent to arbitration before the dispute has arisen (by way of its 'open-ended', standing offer to arbitrate), whereas the investor regularly expresses its consent after the dispute has broken out (by accepting the host state's standing offer, which is generally done in practice by filing a request for arbitration pursuant to the arbitration rules envisaged in the relevant treaty). For instance, based on this asymmetry, one commentator has opined that, while 'secondary consent may make sense where the arbitration agreements are already concluded when the disputes arise' (for instance, in case of commercial multi-party arbitrations), such secondary consent is 'not really necessary' in investment treaty arbitration when multiple investors decide to claim jointly in one single proceeding. This is because:

[T] he request of a special/secondary consent would clearly 'overturn the equilibrium' of investment arbitration, where the host State's consent to arbitration 'given in advance' has to be seen as a procedural guarantee for stimulating and protecting foreign investments. Indeed, the special/secondary consent would de facto amount to 'a counteroffer made by the investors' to the host State 'after' the investment has been done and 'after' the dispute has arisen. The host State would then be able to accept or reject this counteroffer. The risk is that the foreign investors could lose the possibility of having their dispute resolved through arbitration in a neutral forum, as the State could reject the investors' counteroffer; in that case, it would as a matter of fact be cost prohibitive for many Claimants to file individual claims [...]. ${ }^{56}$

distinction-between-jurisdiction-and-admissibility-part-ii/> [accessed 30 April 2014]: 'Although the [Abaclat] majority's decision on consent is certainly controversial, it is sound in principle. Unlike an arbitration clause in a typical commercial contract, offers to arbitrate in investment treaties are open to the world of qualified investors. The offer to arbitrate is made to investors with investments. In principle, this offer to the world should be able to be accepted by a multitude of investors. If there is consent to arbitrate where one shareholder holds 100,000 shares, why is there not equally consent when there are 100,000 shareholders each holding one share?'.

${ }^{56}$ A M Steingruber, 'Case Comment, Abaclat and Others v Argentine Republic: Consent in Large-scale Arbitration Proceedings' (2012) 27 ICSID Rev-FILJ 237, 245. 
We also note that the dissenting opinions in both the Abaclat and Ambiente cases emphasised the possible need for the respondent state's additional and explicit consent to collective procedures by referring to a principle of 'secondary consent, ${ }^{57}$ which they appeared to derive from the following passage from a law review article by Strong (who has written widely on mass and class claims in arbitration):

[...] the first question raised in every arbitration is whether the parties have agreed to arbitrate this particular dispute. This issue which can be termed 'primary consent' - is usually not directly challenged in class arbitration, since all the parties have signed agreements indicating their consent to arbitrate their disputes. Instead, class arbitration focuses for the most part on what can be called 'secondary consent', meaning consent to this particular type of procedure. This concept is by no means unique to class disputes, since traditional multiparty arbitrations are also required to establish secondary consent in cases where the arbitration agreements are silent or ambiguous as to multiparty treatment.$^{58}$

However, in a recent case comment, Strong has clarified that "both dissents failed to recognize that the phrase "secondary" was not used in [her] law review article to mean "additional", but was instead used as a synonym for "subordinate". 59 Strong emphasises that, given that most jurisdictions accept that even core 'primary consent' issues (such as whether to arbitrate) can be demonstrated by implicit means, ${ }^{60}$ the principle outlined in her original article suggested that it would be illogical to require a more rigorous standard of consent in situations involving matters of secondary (i.e. subordinate) concern

${ }^{57}$ Abaclat $v$ Argentine Republic (Decision on Jurisdiction and Admissibility, Dissenting Opinion, Georges Abi-Saab, 28 October 2011), para 173; Ambiente v Argentine Republic (Decision on Jurisdiction and Admissibility, Dissenting Opinion, Santiago Torres Bernardez, 2 May 2013) para 103.

${ }^{58}$ S I Strong, 'Does Class Arbitration the Nature of Arbitration? Stolt-Nielsen, AT\&T, and a Return to First Principles' (2012) 17 Harvard Negotiation LR 201, 251-2 (citations omitted).

${ }^{59}$ S I Strong, 'Case Comment: Ambiente Ufficio SpA and others v Argentine Republic: Heir of Abaclat? Mass and Multiparty Proceedings' (2014) 29 ICSID Rev-FILJ 149, 151.

${ }^{60}$ For example, non-signatories can be brought into an arbitral proceeding through reliance on principles based on implicit consent, including those based on agency, assumption, alter ego, piercing the corporate veil, estoppel, incorporation by reference and the group of companies doctrine. 
than in cases involving matters of primary concern'. 61 Thus, in her view, if questions regarding mass or collective proceedings were to be viewed as secondary concerns (i.e. procedural in nature), then it is neither necessary nor desirable to subject such questions to a stricter rule of construction than exists with respect to the agreement to arbitrate and such questions should equally be amenable to implicit consent, if not more so.

On this question of consent, this article does not purport to undertake a detailed analysis of the soundness of the reasoning of the majority and dissenting opinions in the Abaclat and Ambiente cases, and of their respective proponents and opponents. No matter what view one adopts in this debate, these contrasting views essentially reflect differences of opinion regarding the propriety of strict construction versus a more purposive interpretive approach. By emphasising the need for explicit, secondary consent to collective procedures in investment treaty arbitration, the dissenting panelists seem to have adopted a 'strict constructionist' approach. ${ }^{62}$ This approach views the decision to proceed as a group as something more than procedural, and as a core concern that is inextricably linked to the decision to arbitrate. On the other hand, the majority appears to have viewed questions regarding mass or collective proceedings as procedural in nature (i.e. question of 'how' the claims are to be resolved), and thus sought to interpret the relevant arbitration agreement in a way that was likely to establish an effective machinery for the settlement of disputes relating to investments covered by the relevant BIT.

It appears unlikely that consensus will ever be achieved on this issue. As one commentator has noted, these types of interpretative distinctions reflect 'deeper uncertainties underlying international investment law', which may not be 'susceptible to technical or doctrinal solutions' alone. ${ }^{63}$

\footnotetext{
${ }^{61}$ See Strong, above n 59, 151, noting that the idea was based on the theory of 'concentric circles' of consent posited by A S Rau, 'Arbitral Jurisdiction and the Dimensions of "Consent"'(2008) 24 Arb Int'l 199, 203.

${ }^{62}$ See S I Strong, 'Class, Mass and Collective Arbitration in National and International Law' (University of Missouri School of Law Legal Studies Research Paper No 2012-35, 10 December 2012) <http://papers.ssrn.com/sol3/papers.cfm?abstract_id=2185084> [accessed 1 May 2014] para 4.9.

${ }^{63}$ A Mills, 'Antinomies of Public and Private at the Foundations of International Investment Law and Arbitration' (2011) 14 JIEL 469, 503. See also S I Strong, 'Mass Procedures as a Form of "Regulatory Arbitration" - Abaclat v Argentine Republic and the International Investment Regime' (2013) 38 J Corp L 259.
} 


\subsection{Interpreting the silence in the ICSID Convention}

In the case of an ICSID arbitration, the claims must also satisfy the additional jurisdictional requirements set out in Article 25(1) of the ICSID Convention, in addition to meeting any jurisdictional requirements of the applicable investment treaty. ${ }^{64}$ Accordingly, in Abaclat and Ambiente, the claimants had to demonstrate that the tribunals had jurisdiction under both the Italy-Argentina BIT and Article 25 of the ICSID Convention.

However, the ICSID Convention is silent on the issue of mass claims or collective proceedings. The Majority and Dissent in both Abaclat and Ambiente adopted widely divergent views of the nature of the silence in question and the power of the arbitral tribunal to address that silence.

\subsubsection{Majority view}

The majority in Abaclat recognised that the current ICSID framework contained no reference to collective proceedings as a possible form of arbitration, but gave limited weight to this silence, holding that it would be contrary to the purpose of the BIT and to the spirit of ICSID to interpret this silence as a 'qualified silence' categorically prohibiting collective proceedings. ${ }^{65}$ It concluded that this silence was to be interpreted as an unintended 'gap', which the tribunal had the power, in principle, to fill. ${ }^{66}$ In particular, the majority noted that, at the time the ICSID Convention was concluded, mass proceedings were 'quasi inexistent' and that the discussions that took place with regard to multi-party arbitrations at the time were inconclusive on the intention to either accept or reject multi-party arbitrations or the admissibility of collective proceedings. ${ }^{67}$ Further, it observed that ICSID provides a standard arbitration mechanism and that, where an investment protected under a BIT providing for ICSID arbitration

\footnotetext{
${ }^{64}$ See e.g. C McLachlan, L Shore \& M Weiniger, International Investment Arbitration: Substantive Principles (2007) MN6.06.

${ }^{65}$ Abaclat $v$ Argentine Republic (Decision on Jurisdiction and Admissibility, 4 August 2011) para 519. This was endorsed by the majority in Ambiente $v$ Argentine Republic (Decision on Jurisdiction and Admissibility, 8 February 2013) para 146: 'Nothing has emerged from the preceding legal analysis that would militate in favour of interpreting the of the ICSID Convention as standing in the way of instituting multi-party proceedings'.

${ }^{66}$ Abaclat $v$ Argentine Republic (Decision on Jurisdiction and Admissibility, 4 August 2011) para 520. The tribunal in Ambiente, by contrast to Abaclat, did not see the need to fill any gaps in the ICSID Rules. The number of claimants (90) could be dealt with under the normal ICSID arbitration framework.

${ }^{67}$ Ibid, para 519.
} 
showed certain particular characteristics, those characteristics may lead the tribunal to make certain adaptations to the standard procedure to give effect to the choice of ICSID arbitration. ${ }^{68}$

Similarly, the Ambiente majority noted that 'some discussions took place at the time of conclusion of the ICSID Convention in regard to multi-party proceedings', which, whilst 'not conclusive as to the intention to either accept or refuse multi-party arbitrations', nonetheless weakened Argentina's claims that 'accepting multi-party arbitrations would extend the jurisdictional basis way beyond the horizon of foreseeability of the drafters of the ICSID Convention. ${ }^{69}$

\subsubsection{Dissenting opinion}

However, in his dissent in Abaclat, Arbitrator Abi-Saab noted that the 'argument of the majority award based on the unforeseeability of collective actions at the time of drafting the Convention, paradoxically bears in favour of interpreting the silence of the ICSID Convention as not extending to cover such an extraordinary type of judicial activity as representative proceedings or class actions. ${ }^{70}$

Similarly, the dissenting opinion in Ambiente noted that interpreting the silence in favour of existence of jurisdiction was not warranted as a matter of public international law. ${ }^{71}$

\subsubsection{Analysis}

The dissenting view has been supported by some academics. For instance, one commentator has opined that, under international law, consent to jurisdiction is the exception and not the default rule and that, when the ICSID Convention is silent as to whether the parties consented to jurisdiction, the tribunals should have found that there was no consent and therefore no jurisdiction. ${ }^{72}$

\footnotetext{
${ }^{68}$ Ibid. However, the majority noted that any adaptations made to the standard procedure 'must be done in consideration of the general principle of due process and must seek a balance between procedural rights and interests of each party'.

${ }^{69}$ Ambiente v Argentine Republic (Decision on Jurisdiction and Admissibility, 8 February 2013) para 132.

${ }^{70}$ Abaclat $v$ Argentine Republic (Decision on Jurisdiction and Admissibility, Dissenting Opinion, Georges Abi-Saab, 28 October 2011) para 166.

${ }^{71}$ Ambiente v Argentine Republic (Decision on Jurisdiction and Admissibility, Dissenting Opinion, Santiago Torres Bernardez, 2 May 2013) para 76.

72 See A Raviv, 'ITA-ASIL 2014: Mass and Class Claims in Arbitration' (Kluwer Arbitration Blog, 22 April 2014) <http://kluwerarbitrationblog.com/blog/2014/04/22/ita-asil-conference-massand-class-claims-in-arbitration> [accessed 30 April 2014], discussing Michael Waibel's views.
} 
Again, a detailed analysis of this debate is beyond the scope of this paper. However, the authors note that it is not entirely clear from the analyses in the Abaclat and Ambiente cases and in academic commentary whether any specific conclusions on the issue of admissibility of collective proceedings can be derived from the drafting history of the ICSID Convention.

First, it appears that discussions on multi-party arbitrations at the stage of drafting of the ICSID Convention are inconclusive, as evidenced by the above discussed disagreement between the majority and dissenting opinions in Abaclat and Ambiente cases.

Secondly, whilst in the initial stages of the drafting of the ICSID Convention litigation by way of an association of persons was envisaged, ${ }^{73}$ this reference to an 'association' no longer appeared by $1964 .^{74}$ Some commentators have questioned whether any significance can be attached to this abandonment. ${ }^{75}$

Finally, at the stage of drafting, there was also a proposal that any claims brought before ICSID have a de minimis value of US $\$ 100,000 .^{76}$ This proposal did not make it to the final draft but may be seen as evidence of an initial aversion to small claims of the sort in Abaclat. However, given that no limit was ultimately imposed, it is also possible to argue that multiple small claims should be possible under the ICSID framework. ${ }^{77}$

See also Weiniger \& McClure, above n 54, 4, noting that there was no need to interpret the silence in the ICSID Convention as a 'gap', since this silence related to the issue of multi-party arbitrations which was considered in negotiations at the time of the drafting of the ICSID Convention.

${ }^{73}$ The commentary to the definition of 'national' in the 9 August 1963 draft of the Convention stated that 'nationals' include both natural and juridical persons as well as associations of such persons': see ICSID, II-1 History of the ICSID Convention: Documents Concerning the Origin and the Formulation of the Convention on the Settlement of Investment Disputes Between States and Nationals of Other States (1968) 170.

${ }^{74}$ By 1964, the draft (which by that stage was closer to the Convention as it was ultimately adopted) no longer has the comment referred to above: ibid, 610-45.

${ }^{75}$ See H van Houtte \& B McAsey, 'Case Comment, Abaclat and others v Argentine Republic: ICSID, the BIT and Mass Claims' (2012) 27 ICSID Rev-FILJ 231, 235.

${ }^{76}$ See ICSID, above n 73, 487.

${ }^{77}$ See van Houtte \& McAsey, above n 75, 235. 


\subsection{Group examination and relationship between claims}

\subsubsection{Abaclat}

According to the majority in Abaclat, Article 44 of the ICSID Convention ${ }^{78}$ and Rule 19 of the ICSID Arbitration Rules ${ }^{79}$ provided the Tribunal with the authority to make procedural adaptations necessary to hear mass claims. The majority found that the necessary adaptations concerned only the method of examination of claims and the manner of representation of the claimants, rather than the substance or the object of the Tribunal's examination. ${ }^{80}$ Although the majority recognised that the procedural adaptations would make it difficult for Argentina to respond to each individual claim, and that each claimant would likely be unable to present a full case, it considered that these limits on the rights of both parties were justified in the interest of overall fairness. ${ }^{81}$

In its attempt to find the 'balance' between restricting certain procedural rights of the parties and adopting a method of examination that could give actual effective protection to the investments, the majority considered the conditions under which it was 'acceptable to change the method of examination from individual to group treatment. ${ }^{82}$ It opined that group examination of claims was acceptable only 'where claims raised by a multitude of claimants are to be considered identical or at least sufficiently homogeneous. ${ }^{83}$ It also drew a distinction between treaty and contractual claims, and held that 'the identity or homogeneity requirement applies to the investment and the rights and obligations deriving therefrom based on the BIT and not to any potential contractual claims. ${ }^{84}$ Thus, in the majority's view, the 'specific circumstances surrounding individual purchases by Claimants of security entitlements, ${ }^{85}$ and the question of whether the claimants had 'homogeneous contractual rights to repayment by Argentina of the

\footnotetext{
${ }^{78}$ Article 44 of the ICSID Convention provides: 'If any question of procedure arises which is not covered by this Section or the Arbitration Rules or any rules agreed by the parties, the Tribunal shall decide the question.'

${ }^{79}$ Rule 19 of the ICSID Arbitration Rules states: 'The Tribunal shall make the orders required for the conduct of the proceeding'.

${ }^{80}$ Abaclat $v$ Argentine Republic (Decision on Jurisdiction and Admissibility, 4 August 2011) paras 529-33.

${ }^{81}$ Ibid, paras 536-9.

${ }^{82}$ Ibid, paras 538-9.

${ }^{83}$ Ibid, para 540(i).

${ }^{84}$ Ibid, para 541.

${ }^{85}$ Ibid, para 542.
} 
amount paid for the purchase of the security entitlements, ${ }^{, 86}$ were irrelevant. For it, the only relevant question was 'whether Claimants have homogeneous rights of compensation for a homogeneous damage caused to them by potential homogeneous breaches by Argentina of homogeneous obligations provided for in the BIT' $^{, 87}$

On the facts of the case, the majority found that the claimants' 'claims deriving from the BIT' were sufficiently homogenous on the basis that: (i) the rights deriving from the claimants' investments and Argentina's obligations to protect those rights were the 'same' with regard to all claimants 'to the extent they derive from the same BIT and the same provisions'; and (ii) each claimant's individual claim arose from the same basic type of financial instrument/investment, each of which was affected in the same way by the same post-default measures undertaken by Argentina. ${ }^{88}$

In his dissenting opinion, Arbitrator Abi-Saab noted that the claims continued to retain their 'individualized character' and it was accordingly not possible for the tribunal to treat those claims judicially as one claim or identical fungible claims. ${ }^{89}$ He criticised the majority's 'sufficient homogeneity' test for conveniently ignoring the specificities of the claims concerning the security entitlements (in terms of price, date of purchase, place of purchase, currency, applicable law, chosen forum, etc.), ${ }^{90}$ and queried how it was possible, for example, for a tribunal to 'evaluate a treaty claim for compensating damages caused to an asset, without knowing (or while making abstraction of) the time the asset was acquired, the price paid for it and the currency of denomination. ${ }^{91}$ In his view, while the level of homogeneity resulting from the fact that the claims arose of the 'same fact pattern' (i.e. Argentina's economic crisis which led to Argentina's default) was 'sufficient for aggregating and registering them for purposes of pretrial management', it was not sufficient for what the majority award referred to as 'group examination', i.e. their examination as if they were one claim. ${ }^{92}$

\footnotetext{
${ }^{86}$ Ibid, para 541.

${ }^{87}$ Ibid.

${ }^{88}$ Ibid, para 543.

${ }^{89}$ Abaclat $v$ Argentine Republic (Decision on Jurisdiction and Admissibility, Dissenting Opinion, Georges Abi-Saab, 28 October 2011) para 140.

${ }^{90}$ Ibid, paras 141-3.

${ }^{91}$ Ibid, para 143.

92 Ibid, para 144.
} 


\subsubsection{Ambiente}

For the majority in Ambiente, while there was no requirement for a specific consent on the part of the respondent state as regards the possibility of multi-party proceedings as such, "[a] different question [was] whether multi-party proceedings in ICSID arbitration presuppose a certain link or relationship between the would-be co-claimants. ${ }^{93}$

In fact, it appears that the claimants in the Ambiente case conceded that there should be a 'reasonable and significant link' between the claims of the persons seeking to bring a multi-party action, and that 'totally unrelated' claims could therefore not be adjudicated in the same arbitration. ${ }^{94}$ In this context, the majority also expressed doubts about whether completely unrelated claims could be brought by a plurality of investors in one and the same arbitration proceeding. $^{95}$

However, in response to Argentina's objection based on the absence of a preexisting contractual relationship among the claimants, the majority considered a number of earlier ICSID decisions involving multi-party arbitrations, and found that the ICSID legal framework could not be interpreted to require that the claimants in a multi-party proceeding must be necessarily connected by a contractual link among themselves. ${ }^{96}$

Ultimately, the Ambiente majority found that a necessary link existed among the claimants in terms of the treaty claims that they sought to pursue jointly, insofar as: (i) they complained about the same illegality allegedly committed by Argentina; (ii) their claims were based on the same provisions of the Argentina-Italy BIT as well as the ICSID Convention; (iii) they had made identical prayers of relief for indemnification for Argentina's measures; and (iv) the factual background on the basis of which they sought to establish their treaty claims was virtually the same for all the claimants. ${ }^{97}$ Although some variation existed in the factual circumstances surrounding the various bonds (as was the case in Abaclat), the Ambiente majority, like its counterpart in Abaclat, considered these variations to be irrelevant because they related to the claimants' contractual claims but not to the treaty claims before the Tribunal. ${ }^{98}$ On this analysis, the Ambiente majority

\footnotetext{
${ }^{93}$ Ambiente v Argentine Republic (Decision on Jurisdiction and Admissibility, 8 February 2013) para 143.

${ }^{94}$ Ibid, para 152.

${ }^{95}$ Ibid, para 153.

${ }^{96}$ Ibid, para 155.

${ }^{97}$ Ibid, para 161.

${ }^{98}$ Ibid, para 162.
} 
concluded that the claims in question were capable of being decided upon in one single multi-party arbitration, and that the Tribunal's competence to decide the case could not be called into question due to a presumed lack of necessary link between the claims that were being brought jointly. ${ }^{99}$

\subsubsection{Analysis: Towards a 'taxonomy' of multi-party proceedings}

Related multi-party arbitrations are well-established in investment treaty jurisprudence. Typically, a 'related multi-party arbitration' encompasses claims emanating from one investment operation and arising as a consequence of, inter alia: (i) related investors claiming jointly (for instance, a multi-party claim brought by joint venture partners in relation to their respective shareholdings in the same locally incorporated special purpose vehicle); ${ }^{100}$ (ii) companies claiming jointly with their parent companies or subsidiaries; ${ }^{101}$ or (iii) the assignment, in part, of the investor's rights to an additional investor.

Where one of these relationships pertains between the claimants or their investments, the number of claimants, of itself, has not historically been problematic. ${ }^{102}$ This is the case even where the claims were brought by claimants of different nationalities under one or several treaties or other legal instruments. For instance, in Noble Energy v Ecuador, ${ }^{103}$ Noble Energy, a US company, and MachalaPower, a subsidiary of Noble Energy incorporated in the Cayman Islands, jointly brought claims against Ecuador in one ICSID arbitration under the US-Ecuador BIT, an investment contract and a concession contract, each of which provided for ICSID arbitration. Ecuador argued that scope of its consent to ICSID arbitration did not extend to an agreement to resolve all these disputes in one arbitration. The tribunal found 'an obvious interdependence between the different disputes', insofar as they stemmed from 'the same facts, the same overall economic transaction, and the same measures', ${ }^{\prime 04}$ and held, after reviewing a

\footnotetext{
${ }^{99}$ Ibid, para 163.

${ }^{100}$ See e.g. Suez, Sociedad General de Aguas de Barcelona SA and InterAguas Servicios Integrales del Agua SA v Argentine Republic, ICSID Case No ARB/03/17 (Decision on Liability, 30 July 2010).

${ }^{101}$ See e.g. AES Corporation and Tau Power BV v Kazakhstan, ICSID Case No ARB/10/16 (Final Award, 1 November 2013).

${ }^{102}$ For a recent example, see Guaracachi America Inc and Rurelec PLC v Bolivia, PCA Case No 2011-17 (Award, 31 January 2014).

${ }^{103}$ Noble Energy Inc and Machalapower Cia. Ltda $v$ Ecuador and Consejo Nacional de Electricidad, ICSID Case No ARB/05/12 (Decision on Jurisdiction, 5 May 2008).

${ }^{104}$ Ibid, para 192.
} 
number of factors, ${ }^{105}$ that there was 'an implied consent to have the pending disputes arising from the same overall economic transaction resolved in one and the same arbitration.' ${ }^{106}$

However, in collective actions other than such related multi-party arbitrations, where it is difficult to identify a clear corporate relationship or sufficient unity of interest among the claimants, the issue of what test(s) a tribunal should apply to decide whether the claims submitted to it should-or, indeed, are capable of being-resolved in a single arbitration appears to remain open.

As discussed above (and as recognised expressly by the Ambiente majority ${ }^{107}$ ), the concept of 'homogeneity' originated in Abaclat as a means of justifying the various procedural adaptations to the method of examination of claims that were being contemplated as a result of the 'mass' nature of the dispute. It may thus be difficult to derive from this case any general requirement of 'connection' or 'link' between the would-be claimants, their respective claims and/or investments that would need to be satisfied by multiple investors in order to bring their claims in one single arbitration proceeding against a host state.

The Ambiente majority also 'left open' the issue as to whether, under Article 25 of the ICSID Convention, there was a requirement of a necessary link between the claims in a multi-party proceeding and, if so, whether such link had to meet some 'minimum standard. ${ }^{108}$ In particular, the majority did not consider it 'necessary' or 'useful' to: (i) elaborate, in the abstract, on the question of whether the claims were required to be 'homogeneous', or whether it was sufficient for the claims to be 'sufficiently comparable', etc.; and (ii) try to devise a general standard or threshold in that regard. ${ }^{109}$

There are also certain pre-Abaclat cases in which unrelated claimants instituted claims which had in common only the fact that they all contended to have been harmed by the same allegedly unlawful acts of the respondent State. For example, in Funnekotter and others $v$ Zimbabwe, ${ }^{110} 14$ Dutch investors, who directly or indirectly owned large commercial farms in Zimbabwe, jointly brought a claim against Zimbabwe, alleging that its land acquisition programme breached its obli-

\footnotetext{
${ }^{105}$ Ibid, paras 198-205.

${ }^{106}$ Ibid, para 194.

${ }^{107}$ Ambiente v Argentine Republic (Decision on Jurisdiction and Admissibility, 8 February 2013) para 159.

${ }^{108}$ Ibid, para 154 .

${ }^{109}$ Ibid.

${ }^{110}$ Bernardus Henricus Funnekotter and others $v$ Zimbabwe, ICSID Case No ARB/05/6 (Award, 22 April 2009) (Bernardus v Zimbabwe).
} 
gations under the Netherlands-Zimbabwe BIT. In this case, as the claimants in Ambiente reasoned, ' $[\mathrm{t}$ ] he only existing link between the individual claimants and their respective claims was that all of them had suffered the same harm by virtue of the measures adopted by the host State, which deprived each one of them of its investment without a just compensation. ${ }^{111}$ During the proceedings, the parties agreed that the Tribunal had the jurisdiction to hear the dispute. ${ }^{112}$ Nevertheless, the Tribunal stressed the 'special competence granted to arbitral tribunals to determine their jurisdiction' and consequently, on its own initiative, carried out an analysis of a number of jurisdictional issues. ${ }^{113}$ As the majority in Ambiente emphasised, "[w] hile the Funnekotter Tribunal thus actively assured itself of its jurisdiction, in no way whatsoever was the issue of the claimants having no contractual relation between themselves or of their jointly brought claims not being sufficiently linked to each other addressed by the Tribunal.'14 There is therefore some arbitral practice confirming that there is no obstacle to unrelated claimants bringing a multi-party claim arising of the same events or circumstances in the host State.

However, in each of the Funnekotter, Abaclat and Ambiente cases, all members of the relevant claimant group were of the same nationality and brought their claims under the same BIT. At least in the Abaclat and Ambiente cases, this fact appears to have had a bearing on the conclusion of the majority that the treaty claims being brought before them were 'homogeneous' or 'linked' and, accordingly, capable of being adjudicated upon in one single arbitration. ${ }^{115} \mathrm{~A}$ question then arises as to how an investment treaty tribunal would deal with a scenario in future large-scale collective claims where, for example, several claimants of multiple nationalities seek to bring their claims under multiple investment agreements jointly in the same arbitration proceeding.

The ability of claimants of different nationalities to jointly pursue a single arbitration under two separate investment agreements was considered recently in Guaracachi v Bolivia. ${ }^{16}$ In this case, the claimants-Guaracachi (a US company)

\footnotetext{
${ }^{111}$ Ambiente v Argentine Republic (Decision on Jurisdiction and Admissibility, 8 February 2013), para 158.

${ }^{112}$ Bernardus $v$ Zimbabwe (Award, 22 April 2009) para 94.

${ }^{113}$ Ibid, paras 93-95.

${ }^{114}$ Ambiente v Argentine Republic (Decision on Jurisdiction and Admissibility, 8 February 2013) para 158.

${ }^{115}$ Abaclat v Argentine Republic (Decision on Jurisdiction and Admissibility, 4 August 2011) para 543; Ambiente v Argentine Republic (Decision on Jurisdiction and Admissibility, 8 February 2013) para 161.

${ }^{116}$ Guaracachi America Inc and Rurelec PLC v Bolivia (Award, 31 January 2014).
} 
and Rurelec (a UK company) - commenced a claim against Bolivia jointly under the US-Bolivia and UK-Bolivia BITs, respectively. Rurelec indirectly owned Guaracachi, and together they owned a 50.001\% shareholding in Empresa Electrica Guaracachi SA, ${ }^{117}$ which they alleged had been nationalised by the Bolivian State. ${ }^{118}$

Whilst Bolivia did not object directly to the number of claimants, it sought to argue that the claimants were not entitled to bring claims under two separate BITs in a single arbitration because the state had not provided its consent for US and UK investors to do so in the express language of the respective BITs. ${ }^{119}$ The claimants argued that the lack of express wording in the BITs was insufficient to exclude Bolivia's consent.

In analysing whether Bolivia had in fact provided its consent, the Tribunal explained the traditional concept of how arbitration provisions in BITs provide an open offer which-when accepted by investors - constitutes a binding arbitration agreement. In this case, the Tribunal found that the offers of arbitration in the UK-Bolivia and the US-Bolivia BITs did not contain any restrictions or conditions that could prevent the claimants from bringing their claims in a single proceeding, and held that silence in the BITs on the issue could not operate so as to limit the scope of Bolivia's consent. ${ }^{120}$

As to the question of a link or relationship between claimants, the Tribunal held that the relevant BITs could not be interpreted as containing some limitation of scope preventing a claimant from submitting an arbitral claim together with another claimant 'when both claims are based on the same alleged facts and on the same alleged breaches although brought under different BITs, provided that each claimant provides its own independent matching consent to arbitration.' ${ }^{121}$ It found that it was 'clear that the object of both claims is the same, since the allegedly unlawful action by Bolivia was also a single one,' ${ }^{122}$ and concluded that, 'given the obvious link between both claimants and the identity of the facts alleged,' ${ }^{123}$ the claimants were not barred from bringing their claims jointly in a single arbitration proceeding, notwithstanding the fact that those claims were made under different BITs.

\footnotetext{
${ }^{117}$ Ibid, para 4.

${ }^{118} \mathrm{Ibid}$, paras $151-60$.

${ }^{119}$ Ibid, para 164.

${ }^{120}$ Ibid, para 341.

${ }^{121}$ Ibid, para 337.

${ }^{122}$ Ibid, para 338.

${ }^{123}$ Ibid, para 340.
} 
However, it is pertinent to note that, even in the Guaracachi case, the multi-party claim under different BITs arose from one investment operation and as a consequence of closely related investors claiming jointly. ${ }^{124}$ It remains to be seen whether a tribunal would seek guidance from these decisions and also accommodate claims under different BITs (or under a multilateral treaty such as the Energy Charter Treaty) against the same host state by multiple investors of different nationalities, where such investors are not part of the same corporate group and where they hold investments in different projects in the same economic sector that are affected by the same events or circumstances in the host state. ${ }^{125}$

Finally, whilst such a situation is less likely to occur, it has not yet been tested as to whether it is possible for one or more investors to pursue their claims against several host states (for example, claims arising in relation to large scale or trans-boundary investments such as inter-state pipelines) in one single arbitration proceeding.

In fact, some recent events suggest that it may be the relationship between the claimants, their claims and/or their investments, as much as the number of claimants, which could be the new jurisdictional battleground in investment treaty arbitration.

For instance, in May 2013, a bloc of ten foreign investors filed a joint request for arbitration against the Czech Republic relating to various measures allegedly affecting their investments in the photovoltaic sector. The claimants relied on a number of treaties in their joint request, including the Energy Charter Treaty, as well as Czech BITs with the Netherlands, Germany, Cyprus, Luxembourg and the United Kingdom. ${ }^{126}$ The Czech Republic objected to the claimants' effort to consolidate their claims together in a single arbitration, and appointed arbitrators

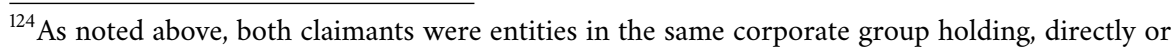
indirectly, shares in the same company.

${ }^{125}$ See e.g. S Wilske, 'Collective Action in Investment Arbitration to Enforce Small Claims - Justice to the Deprived or Death Knell for the System of Investor-State Arbitration?' (2012) 5 (2) Contemp Asian Arb J 165, 184: 'The result of Abaclat could be explored by investors equally affected by similar State measures. For example, multiple investors with small investments in a single sector, subject to a law expropriating their investments, could attempt to pursue aggregated proceedings even though each investor holds a separate investment vehicle'. However, the same author also notes (ibid, 186) that if a group of investors had differing claims on the basis of different contracts, property rights or other instruments of investment, aggregation would prove more difficult'.

${ }^{126}$ L Peterson, 'Following PCA decision, Czech Republic thwarts move by solar investors to sue in single arbitral proceeding; meanwhile Spain sees new solar claim at ICSID' (IA Reporter, 1 January 2014) <http://www.iareporter.com/articles/20140102> [accessed 1 May 2014]. 
in what it considered to be six separate cases, only agreeing to the consolidation of claims if the claimants were affiliates or if they had allegedly invested in the same operation. ${ }^{127}$

Similarly, the Turkmenistan has recently raised preliminary objections to a move by a bloc of 22 Turkish claimants, many of whom were alleged to have unrelated business ventures in Turkmenistan, to bring a single multi-party arbitration claim under the Turkey-Turkmenistan BIT. Rather than seeking to block the constitution of a single arbitral tribunal, however, the government agreed to appoint an arbitrator on the condition that the resulting tribunal would first address Turkmenistan's objection to the multi-party nature of the proceeding. ${ }^{128}$

\section{Conclusion}

Notwithstanding the various vexed issues discussed above, the decisions in Abaclat and Ambiente may have significant practical implications. Historically, large corporations and high net worth individuals have resorted to treaty arbitration in order to seek redress in relation to typically very large investments. Were the Abaclat and Ambiente awards to herald the introduction of mass or collective claims into the mainstream of investment treaty practice, ${ }^{129}$ ISDS provisions could also become a means for collective redress of wrongs to small shareholders or stakeholders. A 'mass' proceeding by shareholders in a publically listed company against a state in which that company has an investment is but one possible scenario.

Certain commentators espousing the so-called 'liberal internationalist' view of investment law have already made a case that investment arbitration be treated

\footnotetext{
${ }^{127}$ This approach, which has resulted in six distinct tribunals, appears to have been effectively endorsed by the Permanent Court of Arbitration in its capacity as appointing authority. In an unpublished decision dated 13 August 2013, the PCA rejected the claimants' request for it to appoint an arbitrator on behalf of the Czech Republic in respect of the original multi-party claim.

${ }^{128}$ L Peterson, 'UNCITRAL tribunal will hear Turkmenistan's argument that a bloc of claimants can't band together to bring a multi-party BIT claim' (IA Reporter, 8 January 2014) $<\mathrm{http}$ //www.iareporter.com/articles/20140108_1> [accessed 1 May 2014].

${ }^{129}$ In particular, commentators have been quick to speculate about the possibility of further mass investment arbitrations resulting from sovereign defaults. See e.g. P Heneghan \& M Perkams, 'The Clawback: Can Arbitration Help Greek Bondholders Gain Redress?' (LegalWeek, 11 May 2012) <http://www.legalweek.com/legal-week/analysis/2173647/clawback-arbitrationhelp-greek-bondholders-gain-redress $>$ [accessed 1 May 2014].
} 
as an internationally recognised component of the administrative law system of states. ${ }^{130}$ Whatever the merits of such a position, the Abaclat and Ambiente majority decisions appear to take it a step closer to reality. This is particularly the case in relation to sovereign debt, not least because, rather than facing the difficulty of enforcing foreign court judgments, bondholders may now have access to the more favourable regime for recognition and enforcement of arbitral awards available under the ICSID Convention. This is likely to be attractive given that, at present, there is no international insolvency regime governing sovereign debt defaults. It might not be hyperbole to suggest that one result of these cases might be to introduce a 'brand new battlefield against sovereign debtors' ${ }^{131}$

In fact, these decisions have the potential to usher in what one commentator has called 'regulatory arbitration,',132 a mechanism whereby private individuals fill certain gaps in the relevant regulatory regime by using arbitration in order to influence future, risk-producing behaviours. ${ }^{133}$ The arbitral process would therefore act not as an ad hoc supplement to public law, but instead as an essential element of a comprehensive regulatory regime. ${ }^{134}$ The bondholders in Abaclat appear to have had such a type of regulatory intent in mind. They noted in their submissions that the 'major threat to the efficiency of foreign debt restructuring [is] rogue debtors such as Argentina' and that 'opening the door to ICSID arbitration would create a supplementary leverage against such rogue debtors and therefore be beneficial to the efficiency of foreign debt restructuring. ${ }^{135}$ Meanwhile, the dissent explicitly disagreed with the propriety of the claimants' use of investment arbitration as a means of creating 'leverage over sovereign debtors.'136

These developments might result in a significant shift in the investment law paradigm, leading to a potentially radical increase in the number and type of investors able to harness the arbitral process to seek redress for breaches of international law. For this reason, Abaclat and Ambiente have the potential to supercharge investment treaty arbitration's 'cosmopolitanist' credentials as a tool which transcends the conventional nation-state model by providing investors

\footnotetext{
${ }^{130}$ See e.g. Van Harten \& Loughlin, above n 3; Kingsbury \& Schill, above n 4.

${ }^{131} \mathrm{Y}$ Li, 'Question the Unquestionable Beauty of a Collective Proceeding for All Sovereign Debt Claims' (2013) 22 Int'l Insolvency R 85, 90.

${ }^{132}$ Strong, above $\mathrm{n} 63$.

${ }^{133}$ Ibid, 271, citing P Luff, 'Risk Regulation and Regulatory Litigation' (2011) 64 Rutgers LR 73, 113.

${ }^{134}$ Ibid, 288.

${ }^{135}$ Abaclat v Argentine Republic (Decision on Jurisdiction and Admissibility, 4 August 2011) para 514.

${ }^{136}$ Abaclat v Argentine Republic (Decision on Jurisdiction and Admissibility, Dissenting Opinion, Georges Abi-Saab, 28 October 2011) para 265.
} 
with access to a regime beyond the domestic legal framework of the host state and implies an additional layer of governance that constitutes a limitation on the sovereignty of states in the field of foreign investments. 